Pharmacology

\title{
Evidence for the Putative Cannabinoid Receptor (GPR55)-Mediated Inhibitory Effects on Intestinal Contractility in Mice
}

\author{
Gracious R. Ross Aron Lichtman William L. Dewey Hamid I. Akbarali \\ Department of Pharmacology and Toxicology, School of Medicine, Virginia Commonwealth University, \\ Richmond, Va., USA
}

\author{
Key Words \\ GPR55 - Cannabinoid receptors · JWH015 · Colon \\ contractility $\cdot 0-1602 \cdot$ lleum
}

\begin{abstract}
Background: Cannabinoids inhibit intestinal motility via presynaptic cannabinoid receptor type I (CB1) in enteric neurons while cannabinoid receptor type II (CB2) receptors are located mainly in immune cells. The recently de-orphanized G-protein-coupled receptor, GPR55, has been proposed to be the 'third' cannabinoid receptor. Although gene expression of GPR55 is evident in the gut, functional evidence for GPR55 in the gut is unknown. In this study, we tested the hypothesis that GPR55 activation inhibits neurogenic contractions in the gut. Methods: We assessed the inhibitory effect of the atypical cannabinoid O-1602, a GPR55 agonist, in mouse colon. Isometric tension recordings in colonic tissue strips were used from either wild-type, $\mathrm{GPR}_{5} 5^{-/-}$or $\mathrm{CB} 1^{-/-} /$ $\mathrm{CB}^{-/-}$knockout mice. Results: 0-1602 inhibited the electrical field-induced contractions in the colon strips from wildtype and $\mathrm{CB}^{-/-} / \mathrm{CB}^{-/-}$in a concentration-dependent manner, suggesting a non- $\mathrm{CB} 1 / \mathrm{CB} 2$ receptor-mediated prejunctional effect. The concentration-dependent response of O-1602 was significantly inhibited in GPR55 $5^{-/}$mice. O-1602 did not relax colonic strips precontracted with high $\mathrm{K}^{+}(80$
\end{abstract}

$\mathrm{mmol} / \mathrm{l})$, indicating no involvement of $\mathrm{Ca}^{2+}$ channel blockade in O-1602-induced relaxation. However, $10 \mu \mathrm{mol} / \mathrm{I}$ O-1602 partially inhibited the exogenous acetylcholine (10 $\mu \mathrm{mol} / \mathrm{l})$-induced contractions. Moreover, we also assessed the inhibitory effects of JWH015, a CB2/GPR55 agonist on neurogenic contractions of mouse ileum. Surprisingly, the effects of JWH015 were independent of the known cannabinoid receptors. Conclusion: Taken together, these findings suggest that activation of GPR55 leads to inhibition of neurogenic contractions in the gut and are predominantly prejunctional.

Copyright $\odot 2012$ S. Karger AG, Basel

\section{Introduction}

The biologically active constituents of Cannabis sativa (marijuana), cannabinoids, have been used or abused for decades for their psychoactive properties. Among over 70 distinct cannabinoid substances in marijuana, $\Delta^{9}$-tetrahydrocannabinol, the main psychoactive ingredient [1], and cannabidiol are the most prevalent and best investigated [2]. There are two 7-transmembrane G-proteincoupled receptors: type 1 (CB1) cannabinoid receptors mediate most of the psychoactive effects, and type 2 (CB2) receptors mediate immunological effects of these

\section{KARGER}

Fax +4161306 1234

E-Mail karger@karger.ch

www.karger.com (c) 2012 S. Karger AG, Basel

0031-7012/12/0902-0055\$38.00/0

Accessible online at:

www.karger.com/pha
Gracious Ross, $\mathrm{PhD}$

Department of Pharmacology and Toxicology

School of Medicine, Virginia Commonwealth University

1112 E. Clay St, Richmond, VA 23298-0613 (USA)

Tel. +1 804828 9689, E-Mail grross@ vcu.edu 
phytocannabinoids. Since the studies of Wagner et al. [3] on endothelial anandamide receptor-mediated mesenteric vasodilation, it has been postulated that a non-CB1/ non-CB2 cannabinoid receptor or 'abnormal cannabidiol (ABN-CBD)' receptor exists [4] and that this receptor could mediate effects of phytocannabinoids and endocannabinoids. Following the identification and cloning of novel human G-protein-coupled receptor 55 (GPR55) [5], several cannabinoid ligands were shown to bind to GPR55 [6], suggesting that it could be a novel cannabinoid receptor. Based on $\left[{ }^{35} \mathrm{~S}\right] \mathrm{GTP} \gamma \mathrm{S}$ assays performed in transfected hGPR55-HEK293 cells, ABN-CBD and its analog O-1602, in which the pentyl side chain was shortened to a methyl group [4], were reported as GPR55 agonists [7-9]. In addition, JWH015 (1-propyl-2-methyl-3(naphthoyl)indole) is also considered to be a CB2/GPR55 receptor agonist [10]. These compounds represent potentially useful pharmacological tools to investigate GPR55 receptors in different physiological systems.

The effects of cannabinoid receptor activation and the role of endocannabinoids in the gastrointestinal tract are now being realized as fairly extensive. CB1 receptor activation reduces intestinal motility, alleviates pain, and affects transient lower esophageal sphincter relaxations and emesis [11, 12]. Although the functional role of CB1 receptors has been extensively studied in the gastrointestinal tract, much less is known about the effects of the recently identified GPR55. Utilizing Northern blot analysis or quantitative polymerase chain reaction methods that detect the receptor at the message level, high levels of human GPR55 mRNA transcripts have been found in brain regions and in several peripheral tissues, such as the ileum $[5,13]$. Rat and mouse GPR55 homologs have also been detected in peripheral tissues including jejunum, ileum, and colon [8, 13, 14]. Recently, Lin et al. [15] have reported that GPR55 ligands could normalize lipopolysaccharide-induced motility disturbances in the gut. However, the mechanisms by which gut motility is influenced by GPR 55 receptors have yet to be verified in functional assays. Since cannabinoids are known to inhibit neurogenic contractions in the gut, we studied the effect of the reported GPR55 agonists, O-1602, an atypical cannabinoid, and JWH015 on the neurogenic (electrical field-stimulated) contractions in mouse colon strips and also intended to determine the mechanisms of action of O-1602. In the present study, we used pharmacological and genetic manipulation approaches to test the hypothesis that activation of GPR55 receptors will result in inhibition of the neurogenic contractions in the mouse intestine.

\section{Materials and Methods}

\section{Animals}

Male Swiss-Webster mice (Harlan, Indianapolis, Ind., USA) as well as male GPR55 ${ }^{-/-}, \mathrm{CB}^{-/-} / \mathrm{CB} 2^{-/-}$double knockout and +/+ mice (Transgenic Colony Facility, Department of Pharmacology and Toxicology, Virginia Commonwealth University, Richmond, Va., USA) backcrossed onto a C57BL/6J background served as subjects. These mice weighed from 25 to $30 \mathrm{~g}$ and were housed 5-6 per cage in a vivarium maintained at $22 \pm 2{ }^{\circ} \mathrm{C}$ on a $12 \mathrm{~h}$ light/ dark cycle. Food and water were available ad libitum. The mice were brought to a test room $\left(22 \pm 2^{\circ} \mathrm{C}, 12 \mathrm{~h}\right.$ light/dark cycle), marked for identification, and allowed $18 \mathrm{~h}$ to recover from transport and handling. Protocols and procedures were approved by the Institutional Animal Care and Use Committee at Virginia Commonwealth University Medical Center and comply with the recommendations of the International Association for the Study of Pain.

\section{Isometric Tension Recording}

One-centimeter segments of distal colon (approximately $1 \mathrm{~cm}$ proximal to the anus) were dissected, flushed off their contents, and trimmed of mesentery. Preparations were suspended in the axis of longitudinal muscle tied to a glass hook under $1 \mathrm{~g}$ of passive tension in $15 \mathrm{ml}$ of siliconized organ baths containing Krebs solution (in mmol/l: $118 \mathrm{NaCl}, 4.6 \mathrm{KCl}, 1.3 \mathrm{NaH}_{2} \mathrm{PO}_{4}, 1.2 \mathrm{MgSO}_{4}$, $25 \mathrm{NaHCO}_{3}, 11$ glucose, and $2.5 \mathrm{CaCl}_{2}$ ) maintained at $37^{\circ} \mathrm{C}$ and bubbled with $95 \% \mathrm{O}_{2}$ and $5 \% \mathrm{CO}_{2}$, and tissues were allowed to equilibrate for $60 \mathrm{~min}$ before start of experiments, with Krebs solution changed every $15 \mathrm{~min}$. Isometric contractions were recorded by a force transducer (GR-FT03; Radnoti, Monrovia, Calif., USA) connected to a personal computer using Acqknowledge382 software (BIOPAC Systems, Inc., Santa Barbara, Calif., USA).

\section{Neurogenic Contractions by Transmural Electrical Field \\ Stimulation}

The gastrointestinal smooth muscle strips can be contracted by inducing acetylcholine (ACh) release by electrical field stimulation (EFS) of the enteric nervous system. Hence, EFS (50 V, 7.5 $\mathrm{Hz}$, unless stated otherwise) was applied through concentric electrodes over longitudinal muscles to produce neurogenic contractions. Cumulative doses of the atypical cannabinoid, O-1602 (100 $\mathrm{nmol} / \mathrm{l}$ to $30 \mu \mathrm{mol} / \mathrm{l})$ or JWH015 $(10 \mathrm{nmol} / \mathrm{l}$ to $10 \mu \mathrm{mol} / \mathrm{l})$ at 0.5 log unit increments were added over the EFS contractions to determine their inhibitory effects on the neurogenic responses. The amplitude of initial contractions stimulated by electrical field before adding any drug was considered $100 \%$ contraction and related to the subsequent inhibitory effects of either O-1602 or JWH015.

\section{Experimental Protocol for Determination of Mechanisms of} Action of GPR55 Agonists

To determine whether the site of action of the agonists is neuronal or postjunctional, colonic tissue strips were contracted by cumulative administration of exogenous ACh [10 nmol/l to 30 $\mu \mathrm{mol} / \mathrm{l}]$, instead of field stimulation, and the concentration-response curves of $\mathrm{ACh}$ were analyzed in the presence and absence of either O-1602 (10 $\mu \mathrm{mol} / \mathrm{l})$ or JWH015 ( $3 \mu \mathrm{mol} / \mathrm{l})$. To assess the involvement of inhibition of $\mathrm{Ca}^{2+}$ influx via voltage-gated $\mathrm{Ca}^{2+}$ channels as possible mechanism in the relaxant effect of O-1602, 
we also assessed the concentration-dependent relaxation induced by $\mathrm{O}-1602$ on colonic tissue strips precontracted by depolarizing solution of high extracellular $\mathrm{K}^{+}(80 \mathrm{mmol} / \mathrm{l})$, which activates voltage-gated $\mathrm{Ca}^{2+}$ channels and also excludes the driving force of the $\mathrm{K}^{+}$currents. The osmolarity of the high $\mathrm{K}^{+}$physiological saline solution was maintained by replacing equivalent moles of $\mathrm{KCl}$ for $\mathrm{NaCl}$ in Krebs solution. Moreover, the cannabinoid receptor subtype involved in the effects of O-1602 and JWH015 was elucidated by performing the EFS experiments in intestinal strips from mice that were genetically deleted of $\mathrm{CB} 1, \mathrm{CB} 2$, both $\mathrm{CB} 1$ and $\mathrm{CB} 2$ or GPR55 receptors.

\section{Drugs Used}

Stock solutions of O-1602 from Organix Inc. (Worburn, Mass., USA) dissolved in ethanol (35-70\%), while rimonabant and JWH015 were from NIDA (Rockville, Md., USA) and Tocris (Minneapolis, Minn., USA), respectively. Lysophosphatidylinositol (LPI), ACh chloride and all other chemicals were purchased from Sigma-Aldrich (St. Louis, Mo., USA).

\section{Statistical Analysis}

Data are presented as mean \pm SEM. O-1602- or JWH015-induced relaxation is expressed as 100 minus the percentage of the initial precontraction to either electrical field or exogenous ACh. The data were analyzed by Prism (GraphPad Software Inc., San Diego, Calif., USA) employing appropriate statistical tools. Means of different groups were analyzed by Student's unpaired t test, one-way ANOVA or two-way ANOVA with Bonferroni post-hoc test. Student's paired t test or two-way repeated measures ANOVA with Bonferroni post-hoc test was used when comparisons were made between control and drug treatments in the same preparation. $\mathrm{p}<0.05$ was considered statistically significant. Individual concentration-response curves of O-1602 or JWH015 were subjected to nonlinear regression analysis to determine $\mathrm{EC}_{50}$, and data are expressed as $\mathrm{pD}_{2}$ (negative logarithm of the molar concentration of the agonist required to produce half-maximal response).

\section{Results}

Inhibitory Effect of the Atypical Cannabinoid O-1602 on Neurogenic Contractions in Mouse Colon

In spite of the fact that the gut expresses GPR55 receptors $[13,16]$, there has been no evidence of its functional relevance. Since endocannabinoids and other cannabinomimetics are known to decrease neurogenic contractions in the gut by inhibiting ACh release from enteric neurons $[17,18]$, we determined whether the atypical cannabinoid, O-1602, considered to be a GPR55 agonist [7-9], can also inhibit the neurogenic contractions in mouse colon. As demonstrated in the representative tracing in figure 1a, EFS-induced depolarization of enteric neurons produced muscle contractions, due to ACh release from these neurons. The atypical cannabinoid O-1602 inhibited these neurogenic contractions concentration dependently (fig. 1a, d). The $\mathrm{pD}_{2}$ and $\mathrm{E}_{\max }$ values of $\mathrm{O}-1602$ for its inhibitory effect were $5.3 \pm 0.08$ and $89 \pm 4 \%, \mathrm{n}=4$, respectively. The vehicle, ethanol (even at maximal final concentration of $0.1 \%$ ), did not affect the electrical fieldstimulated contractions (fig. 1b). As a positive control, we confirmed neurogenic contractions by the inhibitory effect of the selective CB1 agonist, WIN 55212-2 on the EFS-evoked contractions (fig. 1c). O-1602 did not relax the colonic tissues precontracted by high $\mathrm{K}^{+}(80 \mathrm{mmol} / \mathrm{l})$ (fig. 1e), confirming the lack of effect of O-1602 on $\mathrm{Ca}^{2+}$ influx-induced contractions. However, O-1602 (10 $\mu \mathrm{mol} / \mathrm{l})$ but not ethanol has a significant but small (21 \pm $3 \%$ ) inhibitory effect on the exogenous ACh-induced contractions (fig. 1f). Therefore, the site of action of the atypical cannabinoid O-1602 appears to be predominantly presynaptic and partially postjunctional (only at high concentrations).

Inhibitory Effect of the Atypical Cannabinoid O-1602 Is Independent of CB1 or CB2 but Dependent on GPR55 Receptors

We next evaluated whether O-1602-induced functional effects in the mouse colon are mediated through GPR55 receptors. Although the so-called abnormal-cannabidiol receptor antagonist O-1918 [19] possesses GPR55 receptor antagonist properties [20], this compound lacks selectivity as it also antagonizes GPR18 [21] and BK(Ca) channels [22]. Therefore, we tested O-1602 over electrical field-stimulated neurogenic contractions in colon tissue strips from GPR55 ${ }^{-/}$knockout mice. O-1602-induced inhibition of neurogenic contractions was significantly reduced in the absence of GPR55 receptors (fig. 2a). The concentration-response curve of O-1602 in the GPR55 ${ }^{-/}$ tissue showed a significant rightward shift compared with colon from wild-type mice. The $\mathrm{pD}_{2}$ and $\mathrm{E}_{\max }$ values of O-1602 for its inhibitory effect were $5.3 \pm 0.08$ and $89 \pm 4 \%$ in wild-type and $4.9 \pm 0.2$ and $53 \pm 2 \%$ in GPR55 ${ }^{-/}$, respectively ( $\mathrm{n}=3-4$ in each group). Since some O-1602 effects at higher concentrations appeared to be GPR55-independent, we evaluated the involvement of $\mathrm{CB} 1$ and $\mathrm{CB} 2$ cannabinoid receptors as well. Therefore, we tested the inhibitory effect of O-1602 over EFS-induced neurogenic contractions in colon tissue strips from $\mathrm{CB}^{-/-} / \mathrm{CB} 2^{-/-}$double knockout mice. As demonstrated in figure $2 \mathrm{~b}, \mathrm{O}-1602$ maintained its inhibitory actions on neurogenic contractions in spite of the simultaneous absence of both $\mathrm{CB} 1$ and $\mathrm{CB} 2$ receptors. The concentrationresponse curves of O-1602 were not significantly different between wild-type and the $\mathrm{CB}^{-1-} / \mathrm{CB}^{-/-}$double knockout mice except at the concentration of $5 \mu \mathrm{mol} / \mathrm{l}$ 


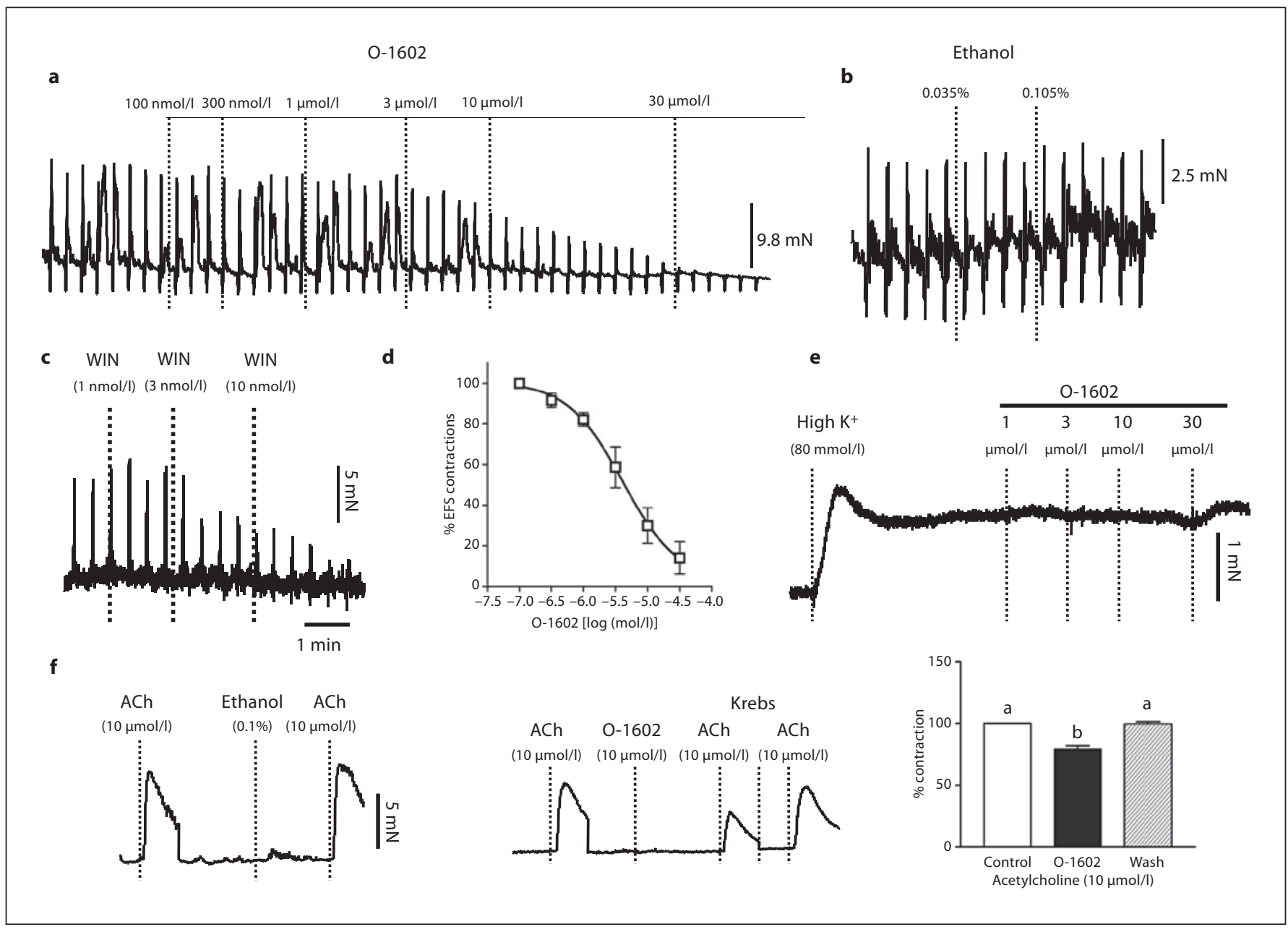

Fig. 1. Effect of the atypical cannabinoid O-1602 on the longitudinal tissue preparations of mouse colon. a Representative tracing showing that O-1602 (100 nmol/l to $30 \mu \mathrm{mol} / \mathrm{l})$ concentration dependently inhibited the neurogenic contractions (electrical fieldinduced) in the distal colon. $\mathbf{b}$ Ethanol alone, even at the maximum final concentration of $0.105 \%$, did not affect the electrical field-induced contractions. c Representative tracing demonstrates that the EFS-induced contractions were neurogenic as a selective CB1 agonist, WIN 55212-2, completely inhibited the contractions potently at $10 \mathrm{nmol} / \mathrm{l}$ concentration. d Concentration-response (inhibition of EFS-evoked contractions) curve of $\mathrm{O}-1602$. e Colonic tissue precontracted by high $\mathrm{K}^{+}(80 \mathrm{mmol} / \mathrm{l})$ was not relaxed by O-1602 suggesting no direct effect on depolarization-induced contraction of smooth muscle. $\mathbf{f}$ Effect of ethanol (0.1\%) alone (left), O-1602 (10 $\mu \mathrm{mol} / \mathrm{l})$ (middle) on exogenous ACh-induced contractions and the corresponding bar graph (right), data analyzed by repeated-measures one-way ANOVA, $\mathrm{n}=3$. (fig. 2c). The $\mathrm{pD}_{2}$ and $\mathrm{E}_{\max }$ values of $\mathrm{O}-1602$ for its inhibitory effect were $5.9 \pm 0.1$ and $73 \pm 4 \%$ in $\mathrm{CB}^{-/-} / \mathrm{CB} 2^{-/-}$ double knockout mice, respectively $(\mathrm{n}=3-4$ in each group). Notably, the $\mathrm{CB}^{-/-} / \mathrm{CB} 2^{-/-}$double knockout group shows some enhanced response in relation to wildtype mice at least at the concentration of $5 \mu \mathrm{mol} / \mathrm{l}$, which could be due to some compensatory effects (enhanced responsiveness of GPR55 receptors) to the lack of both cannabinoid receptors.
Inhibitory Effect of JWH015, a CB2/GPR55 Agonist on Neurogenic Contractions in Mouse Ileum

$\mathrm{CB} 2$ receptors have been found predominantly in the peripheral immune system and DRG cells while their role in intestinal contractility is not known in normal mice. Since JWH015 has inhibitory effects on neurogenic contractions in guinea pig ileum [23], we determined whether GPR55 receptors contribute to the effects of JWH015 in mouse ileum. Compared to the wild-type mice, the in- 


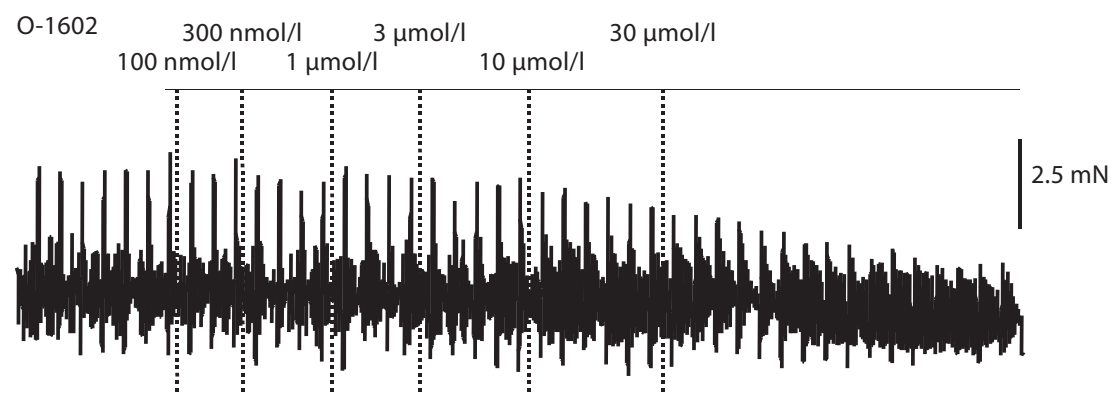

b
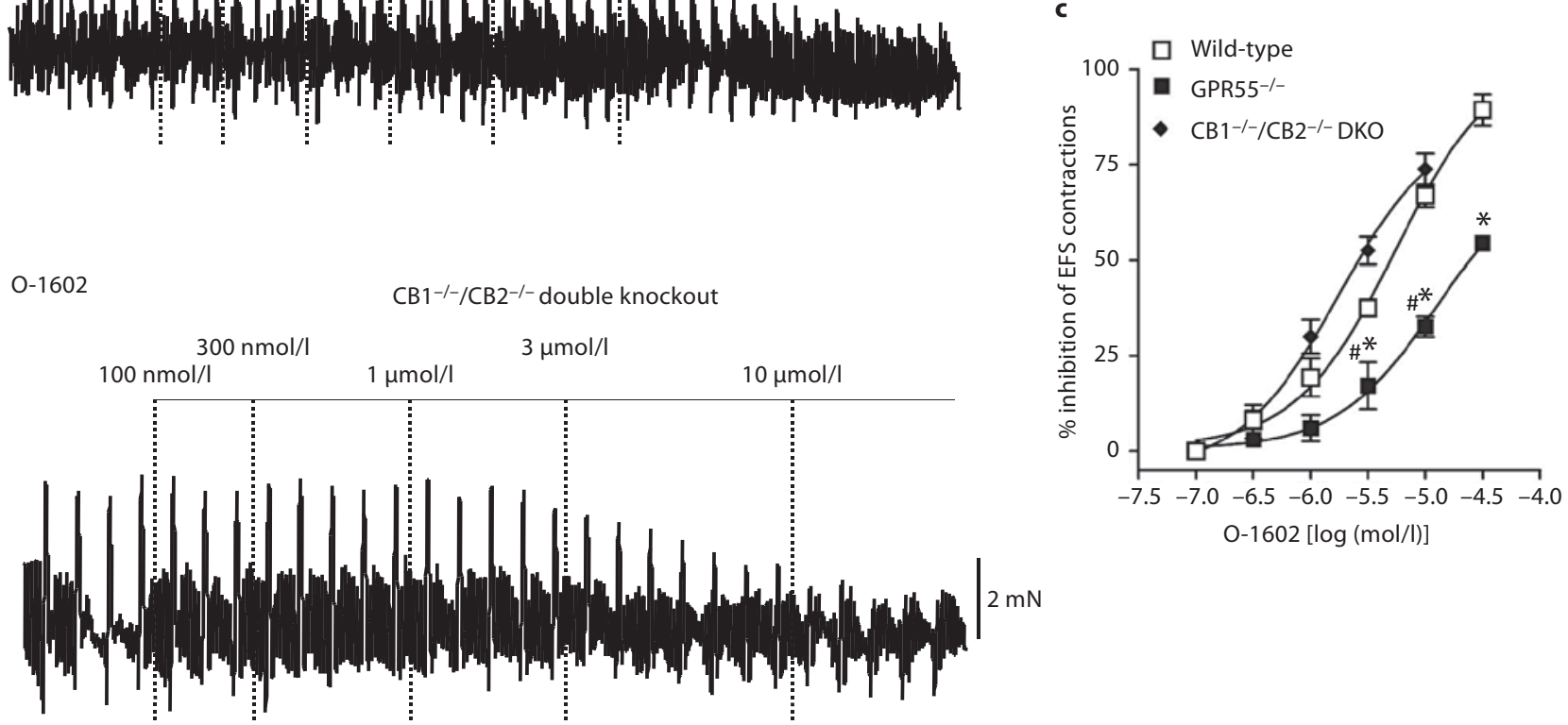

Fig. 2. Effect of O-1602 on neurogenic contractions in colon from knockout mice. a, b Representative tracings that demonstrate the inhibitory effect over neurogenic contractions in mouse colon from a GPR $55^{-/-}$and $\mathbf{b} \mathrm{CB}^{-/-} / \mathrm{CB} 2^{-/-}$double knockout mice. c The corresponding graphs showing concentration-response (inhibition of contraction) curves of O-1602 in GPR $55^{-/-}$and $\mathrm{CB1}^{-/-}$ $\mathrm{CB}_{2}{ }^{-1-}$ double knockout mice. The potency and efficacy of O-1602 was significantly reduced with the deletion of GPR55 but not with the deletion of both CB1/CB2 receptors versus wild-type. The concentration-response curves were subjected to non-linear regression for calculation of $\mathrm{pD}_{2}$ values. Data are mean \pm SE. $\mathrm{n}=$ 3-4. Data were analyzed by two-way ANOVA followed by Bonferroni's posttest. ${ }^{*} \mathrm{p}<0.05$ vs. wild-type; ${ }^{\#} \mathrm{p}<0.05$ vs. $\mathrm{CB}^{-/-}$ $\mathrm{CB} 2^{-/-}$double knockout. hibitory effect of JWH015 on the neurogenic contractions was not significantly affected by the absence of either CB2 (fig. 3a, b), GPR55 (fig. 4a, d), CB1 (fig. 5b) or CB1/2 (fig. 6a) receptors. Moreover, pharmacological experiments using antagonists of CB1, rimonabant (300 nmol/l) (fig. 5a) or GPR55, cannabidiol ( $5 \mu \mathrm{mol} / \mathrm{l}$ ) (fig. 4c) showed no significant difference compared to the corresponding controls. The respective $\mathrm{pD}_{2}$ and $\mathrm{E}_{\max }$ values of JWH015 for its inhibitory effect are given in table 1 . Since the inhibitory effects of JWH015 were independent of cannabinoid and GPR55 receptors, we assessed whether JWH015 directly affects muscarinic contractions by determining its effects on exogenous ACh-induced concentrationdependent contractions. Preincubation of JWH015
( $3 \mu \mathrm{mol} / \mathrm{l}$ ) significantly reduced the $\mathrm{E}_{\max }$ of acetylcholine-induced contractions from $107 \pm 3$ to $67 \pm 4 \%$, without affecting $\mathrm{pD}_{2}$ values $(5.8 \pm 0.1$ vs. $6.0 \pm 0.1$; fig. $6 \mathrm{~b}$ ) suggesting an antagonistic effect on muscarinic receptors. However, it is not clear whether the site of action is at receptor level or at some downstream signaling molecule, which needs further investigations.

\section{Discussion}

The salient finding from this study is that we have shown for the first time functional evidence for GPR55mediated neurogenic effect on intestinal contractility. 


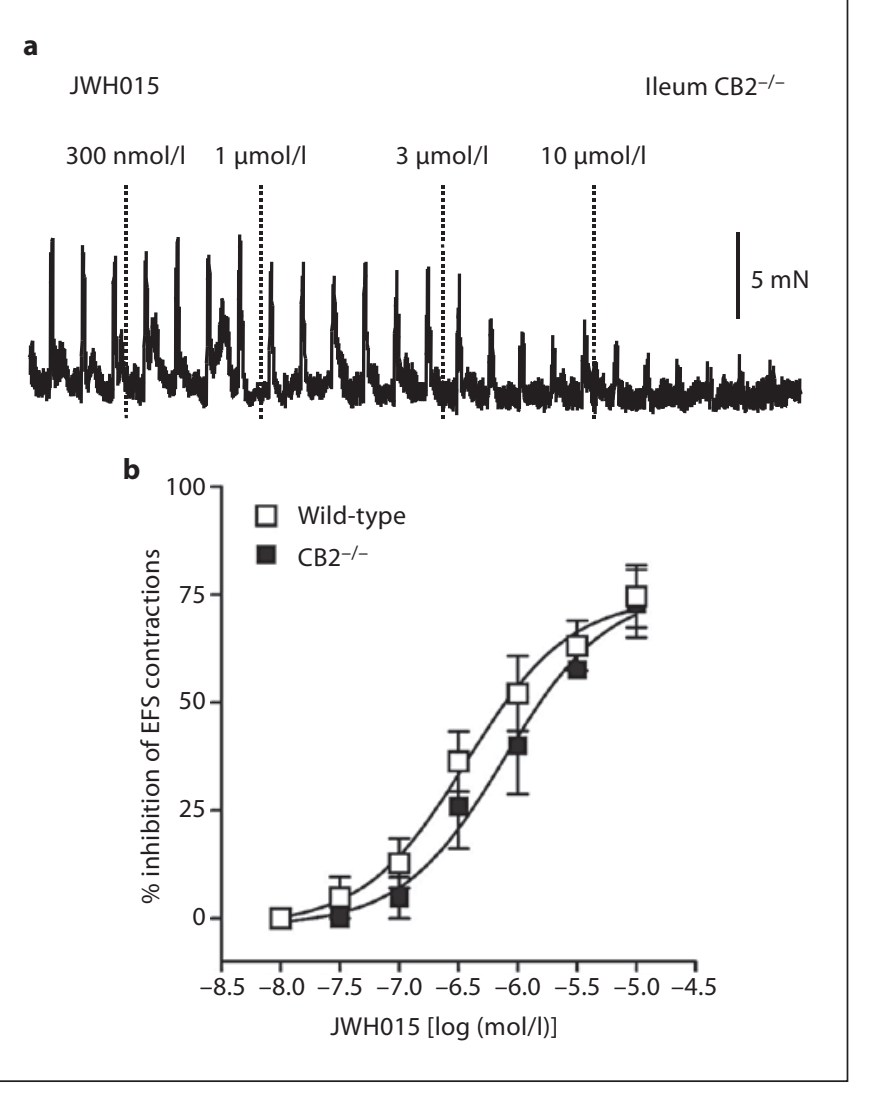

Fig. 3. Effect of JWH015, a CB2/GPR55 agonist, on neurogenic contractions in mouse ileum. a Representative tracings that demonstrate the inhibitory effect over neurogenic contractions in mouse colon from $\mathrm{CB} 2^{-/-}$knockout mice. $\mathbf{b}$ Comparison of concentration-response curves of JWH015 between wild-type (open squares) and $\mathrm{CB} 2^{-/-}$(filled squares) mice. The $\mathrm{pD}_{2}$ values were calculated by subjecting the dose-response curves to non-linear regression analysis. Each data point represents mean $\pm \mathrm{SE}$, analyzed by two-way ANOVA followed by Bonferroni's posttest, $\mathrm{n}=$ $3-4$.

This conclusion is based on our observation that the atypical cannabinoid, O-1602, a GPR55 agonist, inhibited the neurogenic contractions in the gut and its effects were mediated through GPR55, but neither CB1 nor CB2 receptors were necessary, as evident from corresponding gene knockout mice. The inhibitory effects of O-1602 are predominantly prejunctional and partially postjunctional (only at high concentrations). Surprisingly, JWH015, considered to be a CB2/GPR55 agonist, inhibits intestinal contractility independently of these receptors.

Two types of cannabinoid receptors, CB1 and CB2 [24, 25], which are part of the endocannabinoid system, are well studied in several physiological systems. CB1 recep-
Table 1. Potency and efficacy parameters of JWH015 in mouse ileum

\begin{tabular}{|c|c|c|}
\hline \multirow[t]{2}{*}{ Group } & \multicolumn{2}{|l|}{ JWH015 } \\
\hline & $\mathrm{pD}_{2}$ & $\mathrm{E}_{\max }, \%$ \\
\hline Wild-type & $6.4(6.7-6.1)$ & $74 \pm 5$ \\
\hline $\mathrm{CB} 2^{-1-}$ & $6.1(6.5-5.7)$ & $76 \pm 7$ \\
\hline GPR55 & $6.0(6.7-5.2)$ & $71 \pm 13$ \\
\hline Wild-type + cannabidiol & $6.5(6.7-6.3)$ & $72 \pm 4$ \\
\hline $\mathrm{CB}^{-1-}$ & $6.8(7.3-6.3)$ & $61 \pm 5$ \\
\hline Wild-type + rimonabant & $6.2(6.4-6.0)$ & $86 \pm 3$ \\
\hline $\mathrm{CB}^{-/-} / \mathrm{CB} 2^{-/-}$double knockout & $5.8(6.4-5.3)$ & $81 \pm 13$ \\
\hline $\mathrm{CB}^{-/-}+\mathrm{SR} 144528$ & $6.0(6.4-5.7)$ & $61 \pm 6$ \\
\hline
\end{tabular}

tor activation can alleviate pain, reduce gastrointestinal motility, and affect transient lower esophageal sphincter relaxations and emesis $[11,12]$. CB2 receptors are located mainly in immune cells and their activation reduces inflammation. However, there have been several lines of pharmacological evidence supporting the existence of additional putative cannabinoid receptors $[4,26]$, such as the recently de-orphanized GPR55 [13, 27, 28]. The functional role of CB1 receptors has been extensively studied in the gastrointestinal tract, however much less is known about the effects of either CB2 receptors or the newly identified GPR55. Previous reports showed expression of GPR55 receptor in the gut at gene level $[13,16]$, although contradictory sequences have been reported for hGPR 55 $[5,29,30]$, which could be due to errors in sequencing as alternative splicing is not possible in the intronless GPR55 gene. Therefore, expression of GPR55 at protein level in the system under study becomes critical for further characterization of these receptors. However, the gene expression of GPR55 in the gut suggests a potential role for these orphan GPCRs in gut physiology. Nevertheless, the exact location of GPR55 receptor expression with respect to enteric nervous system, smooth muscle cells, mucosa or other gut cell type remains to be characterized.

The objective of the present study was to elucidate the function of GPR55 receptors in mouse colon using the atypical cannabinoid O-1602, generally considered and used as a pharmacological GPR55 agonist [7-9]. As endocannabinoids, phytocannabinoids and their analogs are known to reduce neurogenic contractions in ileum by suppression of ACh release from enteric neurons [17, 18], we determined whether activation of the GPR55 receptor by $\mathrm{O}-1602$ would also inhibit neurogenic contractions in mouse colon. GPR55 appears to mediate the concentra- 


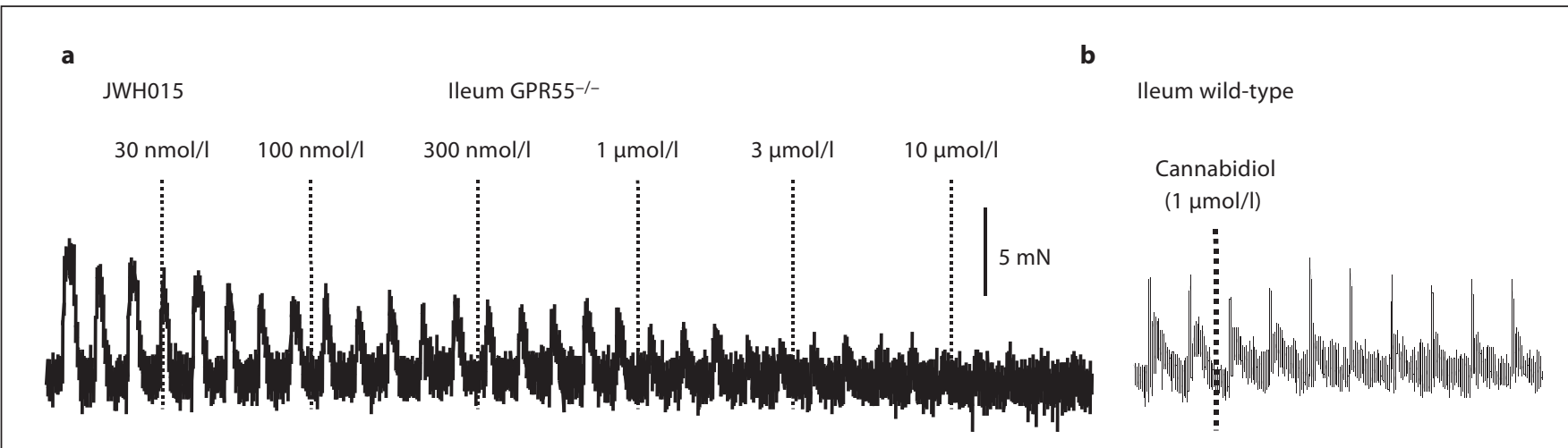

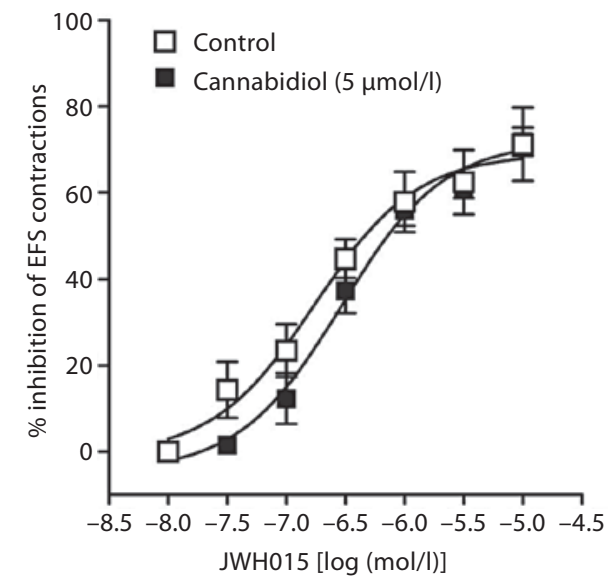

d

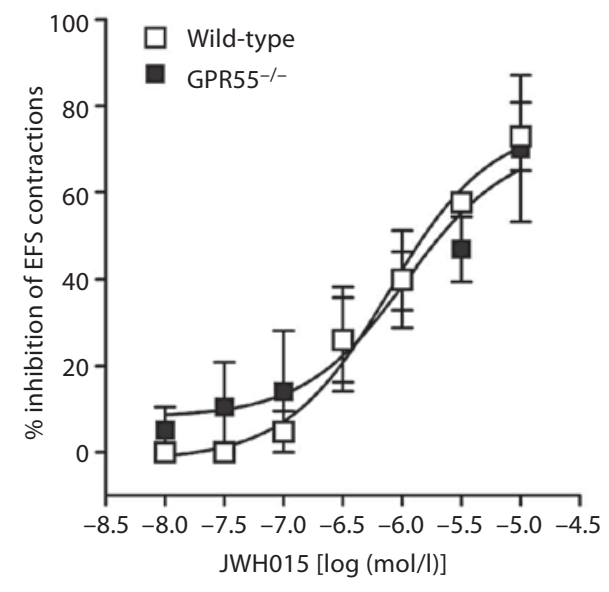

Fig. 4. a-d Effect of JWH015, a CB2/GPR55 agonist, on neurogenic contractions in ileum from knockout mice. Representative tracings that demonstrate the inhibitory effect over neurogenic contractions in mouse colon from GPR $55^{-/-}$knockout mice (a) and lack of effect of cannabidiol $(1 \mu \mathrm{mol} / \mathrm{l})$, considered to be a GPR55 antagonist, on EFS contractions of ileum from wild-type mice (b). Comparison of concentration-response curves of

tion-dependent inhibitory effect of O-1602 over the electrical field-stimulated contractions because the $\mathrm{E}_{\max }$ value of this compound was significantly reduced in colon strips from GPR55 $5^{-/-}$compared to tissue from GPR55 $5^{+/+}$ mice. We also evaluated the involvement of the two accepted cannabinoid receptor subtypes, CB1 and CB2, by testing the O-1602-induced inhibition of neurogenic contractions in colon tissue strips from $\mathrm{CB}^{-/-} / \mathrm{CB} 2^{-/-}$mice. The finding that O-1602 inhibited the contractions with similar $\mathrm{pD}_{2}$ and $\mathrm{E}_{\max }$ values between double knockout and wild-type mice rules out the involvement of these traditional cannabinoid receptors. The affinity of O-1602
JWH015 c wild-type control (open squares) versus wild-type in the presence of cannabidiol (filled circles) and $\mathbf{d}$ wild-type (open squares) versus GPR55 ${ }^{-/}$(filled circles) mice. The concentrationresponse curves were subjected to non-linear regression for calculation of $\mathrm{pD}_{2}$ values. Each data point represents mean $\pm \mathrm{SE}$, analyzed by two-way ANOVA followed by Bonferroni's posttest, $\mathrm{n}=3-5$. for GPR55 receptors is not clear because $\mathrm{EC}_{50}$ values range from nano- to micromolar concentrations and depend on the functional endpoint and cellular systems [69]. The data in the present study are consistent with the affinity of O-1602 being in the micromolar range. Although the relatively high concentrations of O-1602 to inhibit contractions raise the likelihood of activating multiple targets, the finding that deletion of GPR55 reduced these effects supports the involvement of these receptors. The use of other GPR55 agonists that possess greater potency and selectivity than O-1602 may help to discern further the physiological function and mecha- 
a

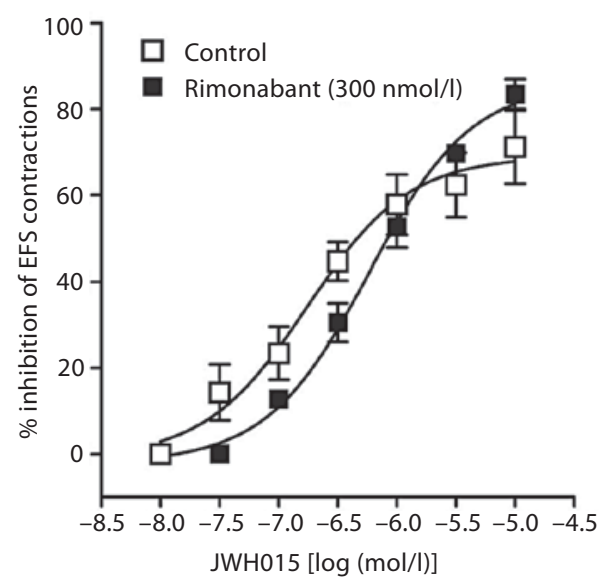

C

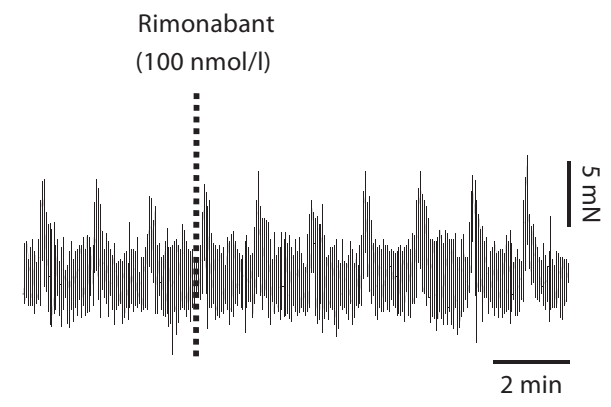

b

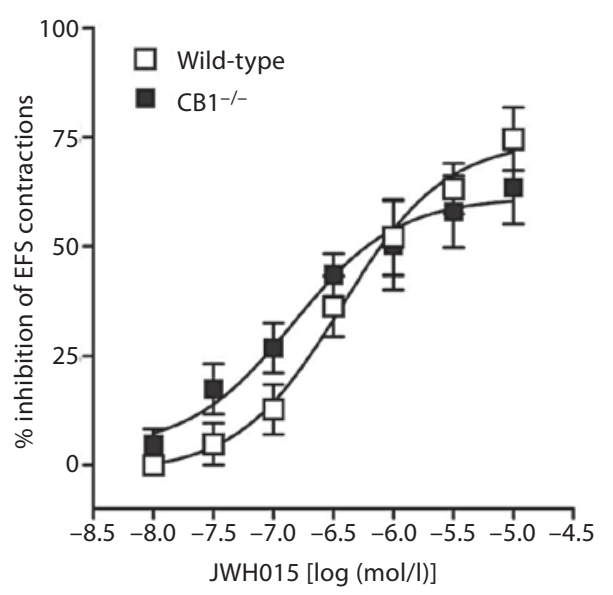

d Lysophosphatidylinositol

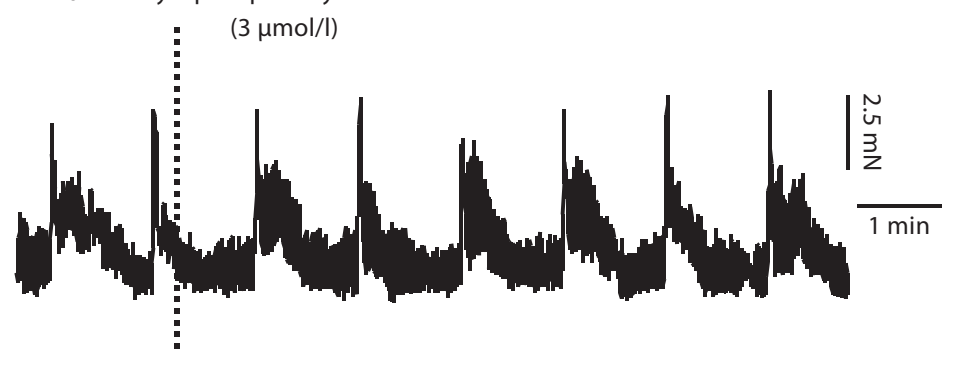

Fig.5. a-d Concentration-dependent response curves of JWH015, a CB2/GPR55 agonist, on neurogenic contraction inhibition in mouse ileum: a control (open squares) versus in the presence of rimonabant $(300 \mathrm{nmol} / \mathrm{l})$, a CB1 receptor antagonist (filled squares) in ileum strips from wild-type mice and $\mathbf{b}$ comparison between wild-type (open squares) and $\mathrm{CB1}^{-/-}$(filled squares). The concentration-response curves were subjected to non-linear re- gression for calculation of $\mathrm{pD}_{2}$ values. Each data point represents mean \pm SE, analyzed by two-way ANOVA followed by Bonferroni's posttest, $\mathrm{n}=3-4$. Representative tracings (c, d) showing lack of effect of rimonabant $(100 \mathrm{nmol} / \mathrm{l})$ (c) or lysophosphatidylinositol $(3 \mu \mathrm{mol} / \mathrm{l})(\mathbf{d})$, considered to be an endogenous ligand for GPR55 receptors, on neurogenic contractions of wild-type mouse ileum. nisms of this receptor. In any event, the results of the present study clearly indicate the actions of O-1602 on the colon are predominantly mediated through GPR55. Although other compounds elicit agonistic effects on GPR55 in vitro such as rimonabant (SR141716A) or AM251 [31], these compounds are not selective. Nonetheless, rimonabant and the reported endogenous ligand for GPR55 lysophosphatidylinositol [32] did not have any effect on the neurogenic contractions in the mouse gut (fig. 5c, d). As of now, further functional characterization of GPR55 receptor is limited by the lack of specific and potent pharmacological modulators. GPR55 is also reported [33] to be activated by the acylethanolamides pal- mitoylethanolamide, anandamide and oleoylethanolamide, which could also be used for further studies of GPR55-mediated effects on intestinal motility.

We further examined the mechanisms of the inhibitory action of O-1602 in mouse colon. Even though O-1602 inhibited the neurogenic contractions, the site of action seems to be predominantly prejunctional and partially postjunctional because it also inhibited significantly (at high concentration) the contractions induced by exogenous ACh, suggesting antimuscarinic effects or effects on downstream signaling molecules involved in smooth muscle contractility as well. Depolarization induced by high extracellular $\mathrm{K}^{+}$opens the plasma mem- 

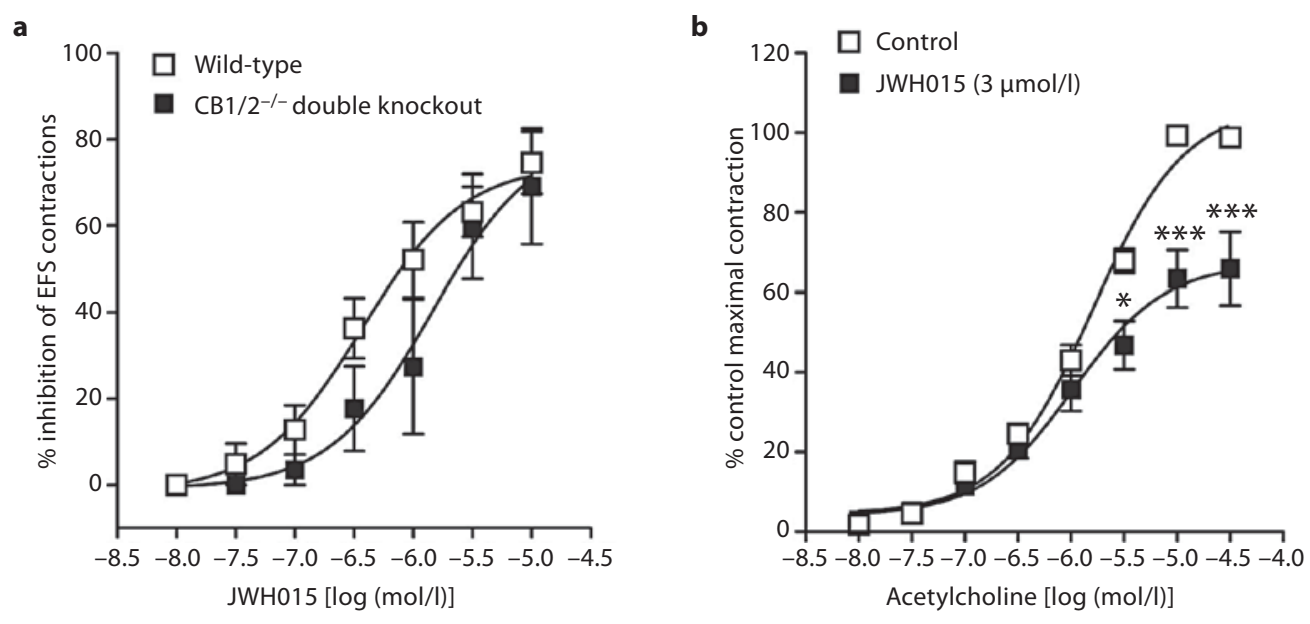

Fig. 6. a Concentration-dependent response curves of JWH015, a CB2/GPR55 agonist, on neurogenic contraction inhibition in ileum from wild-type (open squares) versus $\mathrm{CB}^{-/-} / \mathrm{CB} 2^{-/-}$double knockout (filled squares) mice. $\mathbf{b}$ Effect of JWH015 on exogenous ACh-induced contractions of ileum from wild-type mice: control (open squares) versus in the presence of JWH015 (3 $\mu \mathrm{mol} / \mathrm{l}$ ) (filled squares). Each data point represents mean $\pm \mathrm{SE}$, analyzed by twoway ANOVA followed by Bonferroni's posttest, $\mathrm{n}=3 .{ }^{*} \mathrm{p}<0.05$, *** $\mathrm{p}<0.001$ considered significant versus control (in the absence of JWH015). brane voltage-gated L-type $\mathrm{Ca}^{2+}$ channels, thereby leading to $\mathrm{Ca}^{2+}$ influx. O-1602 did not affect the high $\mathrm{K}^{+}$-induced contraction, ruling out an inhibitory effect on $\mathrm{Ca}^{2+}$ influx.

The role of $\mathrm{CB} 2$ receptors in the gastrointestinal tract is uncertain. In an earlier study, the increased gastrointestinal transit induced by the Gram-negative bacterial endotoxin, lipopolysaccharide, was reduced to normal transit by $\mathrm{CB} 2$ agonist. Hence, activation of $\mathrm{CB} 2$ receptor in response to lipopolysaccharide is suggested as a mechanism for the re-establishment of normal gastrointestinal transit after an inflammatory stimulus [34]. Also, JWH015 reduces motility in the croton oil model of intestinal inflammation [35]. Interestingly, hitherto, there is no evidence for any functional role of $\mathrm{CB} 2$ receptors in the neurogenic contractions of the normal gut. However, in inflamed gut (i.e. lipopolysaccharide-treated), another CB2 agonist, JWH133, reduced the enhanced contractile response in a concentration-dependent manner [36]. Unlike the intestinal preparations, in mouse gastric preparations, JWH015 is demonstrated to inhibit the EFS-evoked cholinergic contractions, which was reduced by AM630, a CB2 antagonist, suggesting a CB2mediated inhibitory effect [37]. Moreover, CB2 receptors have been found predominantly in the peripheral immune system and DRG cells, suggesting no role for CB2 receptors in the regulation of gut motility by enteric neurons. We used JWH015, considered to be a dual CB2/ GPR55 agonist with the twin idea of elucidating the role of each of these receptors in the contractility of intestine. Surprisingly, the inhibitory effects of JWH015 were not at all affected by genetic deletion of either CB2 or GPR55 receptors. Of note, JWH015 has also been shown to mediate its inhibitory effects in guinea pig ileum via $\mathrm{CB} 1$ receptors that are sensitive to SR141716A. But, in the present study with the mouse ileum, neither pharmacological inhibition of CB1 receptors by SR141716A (rimonabant) nor genetic deletion of $\mathrm{CB} 1$ receptors affected the JWH015 effects. It has to be noted that the $\mathrm{EC}_{50}$ value of JWH015 is about one order in magnitude higher in mouse ileum (i.e. micromolar range in the current study) than in the guinea pig ileum (i.e. submicromolar range) [23]. Interestingly, the same group also found that JWH015 was highly potent in the mouse vas deferentia with an $\mathrm{EC}_{50}$ value in the subnanomolar range; however, these effects were non-CB1 receptor-mediated [23]. Thus, the effects of JWH015 appear to be dependent on the system and expression/distribution profile of different cannabinoid receptor subtypes. Since the $\mathrm{pD}_{2}$ values are much lower and JWH015 effects in the mouse ileum are still present in the various knockout mice used in the present study, its underlying mechanism of action 
is most likely independent of CB1, CB2 and GPR55 receptors in the mouse gut.

In conclusion, the atypical cannabinoid O-1602, a GPR55 agonist, produces its inhibitory effect in the colon via a GPR55-dependent mechanism of action and independent of $\mathrm{CB} 1$ or $\mathrm{CB} 2$ receptors. Similar to the site of action by established cannabinoids, which mostly occur presynaptically in the gut, the atypical cannabinoid O-1602 also acts predominantly prejunctional and partially postjunctional (at high concentration). The effects of JWH015 in the gut are independent of GPR55, CB1, and $\mathrm{CB} 2$ receptors. This study reveals novel functional effects and mechanisms of the atypical cannabinoid O-1602 and GPR55 receptors in the gut, which could have therapeutic benefit in management of intestinal dysmotility in various pathological conditions.

\section{Acknowledgements}

The authors are grateful to NIH and VCU as this work was supported by NIH grants to H.A., W.D. and A.L. (DK046367, DA024009, P01DA009789, P50DA005274) and a Virginia Commonwealth University A.D. Williams grant (\#648729) to G.R.

\section{References}

1 Dewey WL: Cannabinoid pharmacology. Pharmacol Rev 1986;38:151-178.

2 Mechoulam R, Gaoni Y: Hashish. IV. The isolation and structure of cannabinolic cannabidiolic and cannabigerolic acids. Tetrahedron 1965;21:1223-1229.

-3 Wagner JA, Varga K, Jarai Z, Kunos G: Mesenteric vasodilation mediated by endothelial anandamide receptors. Hypertension 1999; 33:429-434.

-4 Jarai Z, Wagner JA, Varga K, Lake KD, Compton DR, Martin BR, Zimmer AM, Bonner TI, Buckley NE, Mezey E, Razdan RK, Zimmer A, Kunos G: Cannabinoid-induced mesenteric vasodilation through an endothelial site distinct from CB1 or CB2 receptors. Proc Natl Acad Sci USA 1999;96: 14136-14141.

5 Sawzdargo M, Nguyen T, Lee D, Lynch K, Cheng R, Heng H, George S, O'Dowd B: Identification and cloning of three novel human G-protein-coupled receptor genes GPR52, PsiGPR53 and GPR55: GPR55 is extensively expressed in human brain. Brain Res Mol Brain Res 1999;64:193-198.

6 Moriconi A, Cerbara I, Maccarrone M, Topai A: GPR55: Current knowledge and future perspectives of a purported 'type-3' cannabinoid receptor. Curr Med Chem 2010;17: 1411-1429.

7 Johns DG, Behm DJ, Walker DJ, Ao Z, Shapland EM, Daniels DA, Riddick M, Dowell S, Staton PC, Green P, Shabon U, Bao W, Aiyar N, Yue TL, Brown AJ, Morrison AD, Douglas SA: The novel endocannabinoid receptor GPR55 is activated by atypical cannabinoids but does not mediate their vasodilator effects. Br J Pharmacol 2007;152:825-831.

$\checkmark 8$ Ryberg E, Larsson N, Sjögren S, Hjorth S, Hermansson N, Leonova J, Elebring T, Nilsson K, Drmota T, Greasley P: The orphan receptor GPR55 is a novel cannabinoid receptor. Br J Pharmacol 2007;152:1092.

-9 Whyte LS, Ryberg E, Sims NA, Ridge SA, Mackie K, Greasley PJ, Ross RA, Rogers MJ:
The putative cannabinoid receptor GPR55 affects osteoclast function in vitro and bone mass in vivo. Proc Natl Acad Sci USA 2009; 106:16511-16516.

10 Lauckner J, Jensen J, Chen H, Lu H, Hille B, Mackie K: GPR55 is a cannabinoid receptor that increases intracellular calcium and inhibits m current. Proc Natl Acad Sci USA 2008; 105:2699.

11 Martin BR, Wiley JL: Mechanism of action of cannabinoids: how it may lead to treatment of cachexia, emesis, and pain. J Support Oncol 2004;2:305-314.

12 Izzo AA, Sharkey KA: Cannabinoids and the gut: new developments and emerging concepts. Pharmacol Ther 2010;126:21-38.

13 Brown AJ: Novel cannabinoid receptors. Br J Pharmacol 2007;152:567-575.

14 Ito J, Ito M, Nambu H, Fujikawa T, Tanaka K, Iwaasa $\mathrm{H}$, Tokita $\mathrm{S}$ : Anatomical and histological profiling of orphan G-protein-coupled receptor expression in gastrointestinal tract of C57BL/6J mice. Cell Tissue Res 2009; 338:257-269.

15 Lin XH, Yuece B, Li YY, Feng YJ, Feng JY, Yu LY, Li K, Li YN, Storr M: A novel CB receptor GPR55 and its ligands are involved in regulation of gut movement in rodents. Neurogastroenterol Motil 2011;23:862,e342.

-16 Schicho R, Bashashati M, Bawa M, McHugh D, Saur D, Hu HM, Zimmer A, Lutz B, Mackie K, Bradshaw HB, McCafferty DM, Sharkey KA, Storr M: The atypical cannabinoid O-1602 protects against experimental colitis and inhibits neutrophil recruitment. Inflamm Bowel Dis 2011;17:1651-1664.

$\checkmark 17$ Heinemann A, Shahbazian A, Holzer P: Cannabinoid inhibition of guinea-pig intestinal peristalsis via inhibition of excitatory and activation of inhibitory neural pathways. Neuropharmacology 1999;38:12891297.

18 Roth SH: Stereospecific presynaptic inhibitory effect of $\Delta^{9}$-tetrahydrocannabinol on cholinergic transmission in the myenteric plexus of the guinea pig. Can J Physiol Pharmacol 1978;56:968-975.

19 Offertaler L, Mo FM, Batkai S, Liu J, Begg M, Razdan RK, Martin BR, Bukoski RD, Kunos G: Selective ligands and cellular effectors of a G-protein-coupled endothelial cannabinoid receptor. Mol Pharmacol 2003;63:699705.

20 Schuelert N, McDougall JJ: The abnormal cannabidiol analogue O-1602 reduces nociception in a rat model of acute arthritis via the putative cannabinoid receptor GPR55. Neurosci Lett 2011;500:72-76.

21 McHugh D, Hu SS, Rimmerman N, Juknat A, Vogel Z, Walker JM, Bradshaw HB: N-arachidonoyl glycine, an abundant endogenous lipid, potently drives directed cellular migration through GPR18, the putative abnormal cannabidiol receptor. BMC Neurosci 2010;11:44.

22 Godlewski G, Offertaler L, Osei-Hyiaman D, Mo FM, Harvey-White J, Liu J, Davis MI, Zhang L, Razdan RK, Milman G, Pacher P, Mukhopadhyay P, Lovinger DM, Kunos G: The endogenous brain constituent $\mathrm{N}$-arachidonoyl L-serine is an activator of large conductance $\mathrm{Ca}^{2+}$-activated $\mathrm{K}^{+}$channels. J Pharmacol Exp Ther 2009;328:351-361.

23 Griffin G, Fernando SR, Ross RA, McKay NG, Ashford ML, Shire D, Huffman JW, Yu S, Lainton JA, Pertwee RG: Evidence for the presence of CB2-like cannabinoid receptors on peripheral nerve terminals. Eur J Pharmacol 1997;339:53-61.

24 Munro S, Thomas K, Abu-Shaar M: Molecular characterization of a peripheral receptor for cannabinoids. Nature 1993;365:61-65.

25 Matsuda L, Lolait S, Brownstein M, Young A, Bonner T: Structure of a cannabinoid receptor and functional expression of the cloned CDNA. Nature 1990;346:561-564.

26 Begg M, Pacher P, Bátkai S, Osei-Hyiaman D, Offertáler L, Mo F, Liu J, Kunos G: Evidence for novel cannabinoid receptors. Pharmacol Ther 2005;106:133-145. 
27 Ross RA: The enigmatic pharmacology of GPR55. Trends Pharmacol Sci 2009;30:156163.

28 Hiley C, Kaup S: GPR55 and the vascular receptors for cannabinoids. Br J Pharmacol 2007;152:559.

-29 Sawzdargo M, George SR, Nguyen T, Xu S, Kolakowski LF, O'Dowd BF: A cluster of four novel human G-protein-coupled receptor genes occurring in close proximity to CD22 gene on chromosome 19q13.1. Biochem Biophys Res Commun 1997;239:543-547.

- 30 Strausberg RL, Feingold EA, Grouse LH, Derge JG, Klausner RD, Collins FS, Wagner L, Shenmen CM, Schuler GD, Altschul SF, Zeeberg B, Buetow KH, Schaefer CF, Bhat NK, Hopkins RF, Jordan H, Moore T, Max SI, Wang J, Hsieh F, Diatchenko L, Marusina K, Farmer AA, Rubin GM, Hong L, Stapleton M, Soares MB, Bonaldo MF, Casavant TL, Scheetz TE, Brownstein MJ, Usdin TB, Toshiyuki S, Carninci P, Prange C, Raha SS, Loquellano NA, Peters GJ, Abramson RD, Mullahy SJ, Bosak SA, McEwan PJ, McKernan KJ, Malek JA, Gunaratne PH, Richards S, Worley KC, Hale S, Garcia AM, Gay LJ, Hulyk SW, Villalon DK, Muzny
DM, Sodergren EJ, Lu X, Gibbs RA, Fahey J, Helton E, Ketteman M, Madan A, Rodrigues $S$, Sanchez A, Whiting M, Young AC, Shevchenko Y, Bouffard GG, Blakesley RW, Touchman JW, Green ED, Dickson MC, Rodriguez AC, Grimwood J, Schmutz J, Myers RM, Butterfield YS, Krzywinski MI, Skalska U, Smailus DE, Schnerch A, Schein JE, Jones SJ, Marra MA: Generation and initial analysis of more than 15,000 full-length human and mouse CDNA sequences. Proc Natl Acad Sci USA 2002;99: 16899-16903.

31 Kapur A, Zhao P, Sharir H, Bai Y, Caron MG, Barak LS, Abood ME: Atypical responsiveness of the orphan receptor GPR55 to cannabinoid ligands. J Biol Chem 2009;284: 29817-29827.

32 Corda D, Iurisci C, Berrie C: Biological activities and metabolism of the lysophosphoinositides and glycerophosphoinositols. Biochim Biophys Acta 2002;1582:52-69.

33 Borrelli F, Izzo AA: Role of acylethanolamides in the gastrointestinal tract with special reference to food intake and energy balance. Best Pract Res Clin Endocrinol Metab 2009;23:33-49.
4 Mathison R, Ho W, Pittman QJ, Davison JS, Sharkey KA: Effects of cannabinoid receptor-2 activation on accelerated gastrointestinal transit in lipopolysaccharidetreated rats. Br J Pharmacol 2004;142: 1247-1254.

35 Capasso R, Borrelli F, Cascio MG, Aviello G, Huben K, Zjawiony JK, Marini P, Romano B, Di Marzo V, Capasso F, Izzo AA: Inhibitory effect of Salvinorin A, from Salvia divinorum, on ileitis-induced hypermotility: crosstalk between $\kappa$-opioid and cannabinoid CB(1) receptors. Br J Pharmacol 2008; 155: 681-689.

36 Duncan M, Mouihate A, Mackie K, Keenan CM, Buckley NE, Davison JS, Patel KD, Pittman QJ, Sharkey KA: Cannabinoid CB2 receptors in the enteric nervous system modulate gastrointestinal contractility in lipopolysaccharide-treated rats. Am J Physiol Gastrointest Liver Physiol 2008;295:G78G87.

37 Mule F, Amato A, Baldassano S, Serio R: Involvement of $\mathrm{CB} 1$ and $\mathrm{CB} 2$ receptors in the modulation of cholinergic neurotransmission in mouse gastric preparations. Pharmacol Res 2007;56:185-192. 